\title{
PENGARUH JENIS DAN PROPORSI PENGGUNAAN TEPUNG JAGUNG TERHADAP DAYA IKAT AIR DAN KUALITAS ORGANOLEPTIK DARI NUGGET AYAM KAMPUNG
}

\author{
The Effect of Different Corn Flour Varieties and Proportions on the Water \\ Holding Capacity and Organoleptic of Chicken Nugget Made from Domestic \\ Chicken Meat

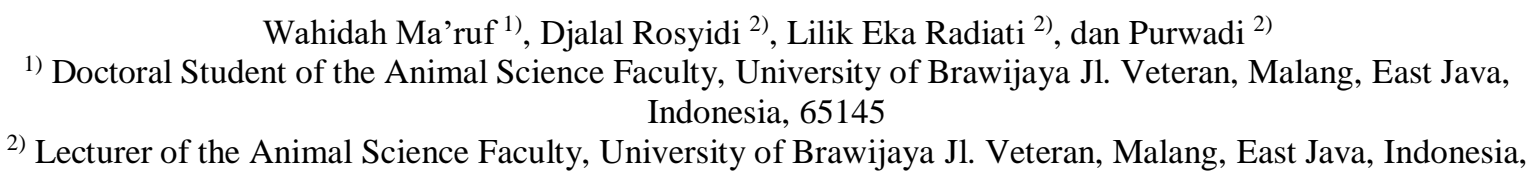
65145

Email: wahidahasri69@gmail.com

Diterima 27 November 2018 ; diterima pasca revisi 18 Maret 2019

Layak diterbitkan 1 April 2019

\begin{abstract}
This research aims to observe the effect of different corn flour varieties and proportions in chicken nuggets made of local chicken meat on its water holding capacity (WHC) and organoleptic characteristics. The research was done by using two-factorials completely randomized design with corn flour varieties as the first factor, and corn flour proportions as the second factor. Five corn varieties were used in this research, which were yellow-corn flour (J1); fluffy-corn flour (J2); purple-corn flour (J3); Provit A1-corn flour (J4); and Provit A2-corn flour (J5). Moreover, the corn flour proportions used in this research were $10 \%$ (T1); $20 \%$ (T2); $30 \%$ (T3); and 40\% (T4). As much as 20 treatment combinations were determined and done in triplicate. The effect of each treatment on the WHC was analyzed with analysis of variance, and followed with LSD test to observe any significant differences. The organoleptic characteristics which consisted of colour, texture, elasticity, flavour, and acceptability were analyzed descriptively. The result showed that the WHC of chicken nugget made from domestic chicken meat were around 47.75-61.64\%, while the J2T3 treatment (Fluffy-corn flour at 30\%) showed lowest WHC, and the highest WHC was showed in J5T4 treatment (Provit A2-corn flour at 40\%). Furthermore, the organoleptic test showed that the J4T1 treatment (Provit A1-corn flour at 10\%) showed the highest score for chicken nugget colour, texture, elasticity, and flavour with the score of 6.43, 5.69, 5.83, and 5.86, respectively. However, the highest acceptability (6.00) was obtained on J5T3 treatment (Provit A2-corn flour at 30\%). It can be concluded that the usage of Provit A1-corn flour at $10 \%$ yield the best characteristics of chicken nugget made from domestic chicken meat.
\end{abstract}

Keywords : Chicken nugget; corn flour; $\beta$-caroten 


\section{ABSTRAK}

Penelitian ini bertujuan untuk mengetahui pengaruh jenis dan proporsi tepung jagung terhadap sifat daya ikat air dan organoleptik dari nugget ayam kampung. Penelitian ini menggunakan rancangan acak lengkap faktorial yang terdiri atas 2 faktor. Faktor pertama ialah 5 (lima) jenis tepung jagung, yaitu: jagung kuning (J1); jagung pulen (J2); jagung ungu (J3); jagung Provit Al (J4); dan jagung provit A2 (J5). Faktor kedua adalah prosentase penggunaan tepung jagung terhadap berat daging ayam yang dipergunakan, yaitu 10\% (T1); $20 \%$ (T2); 30\% (T3) dan 40\% (T4). Dari kedua faktor tersebut diperoleh 20 kombinasi perlakuan, dimana setiap kombinasi perlakuan diulang sebanyak 3 kali. Pengaruh perlakuan terhadap sifat daya ikat air dianalisis menggunakan analisis kergaman, dan dilanjutkan dengan uji beda nyata terkecil (BNT). Data kualitas organoleptik di analisis secara statistik deskriptif. Variabel yang diukur meliputi analisis sifat fisik daya ikat air, dan organoleptik, meliputi: warna, tekstur dan kekenyalan, cita rasa, dan penerimaan umum. Hasil penelitian menunjukkan, uji daya ikat air dari nugget ayam kampung berada pada kisaran 47,75 - 61,64\%, dimana perlakuan J2T3 (jagung pulen taraf penggunaan $30 \%$ ) memiliki prosentasi daya ikat air terrendah, sedangkan yang tertinggi pada perlakuan J5T4 (jagung provit A2 taraf penggunaan 40\%). Penggunaan bahan pengisi dari kelima jenis tepung jagung (J1, J2, J3, J4 dan J5) pada taraf $40 \mathrm{~g}(\mathrm{T1})$ diperoleh daya ikat air antara 50,02 - 55,36\%. Hasil uji organoleptik terhadap nugget ayam kampung, menunjukkan bahwa kombinasi perlakuan J4T1 (jagung Provit Al dengan taraf 10\%) memperoleh nilai tertinggi untuk warna, tekstur, kekenyalan, dan cita rasa, dengan skor masing-masing 6,43, 5,69, 5,83 dan 5,86, sedangkan untuk kategori "penerimaan umum", nilai tertinggi diperoleh pada perlakuan J5T3 (jagung Provit A2 dengan taraf 30\%), dengan skor 6,00. Dari penelitian ini dapat disimpulkan, bahwa penggunaan bahan pengisi tepung jagung Provit Al dengan taraf $10 \%(40 \mathrm{~g})$ memberikan hasil nugget ayam kampung dengan karakteristik kualitas nugget ayam kampung yang terbaik.

Kata kunci: Nugget ayam; tepung jagung; $\beta$-karoten

\section{PENDAHULUAN}

Salah satu sumber protein hewani yang paling digemari masyarakat ialah daging ayam. Ini disebabkan karena daging ayam memiliki kandungan asam amino essensial yang lengkap dan seimbang, disamping kandungan asam lemak tidak jenuh. Daging ayam juga memiliki kandungan mineral, seperti natrium, kalium, magnesium, kalsium, besi, fosfor, sulfur, chlor dan iodium. Berbagai jenis vitamin, antara lain niacin, riboflavin, thiamin dan vitamin $\mathrm{C}$ juga terkandung dalam daging ayam (Koswara, 2009). Permintaan konsumen akan daging ayam mulai bergeser dari daging ayam broiler ke daging ayam kampung. Masruhah (2008) menyatakan bahwa konsumen lebih menyukai daging ayam kampung antara lain karena lebih padat, rasanya lebih gurih, kandungan lemak atau kolesterolnya rendah dan tinggi kandungan proteinnya. Kekhawatiran akan adanya residu antibiotik atau bahan kimia dalam tubuh ayam broiler juga menjadi faktor pemicu konsumen
*Corresponding author:

Wahidah Ma'ruf

Email:wahidahasri69@gmail.com

Doctoral Student of the Animal Science Faculty, University of Brawijaya Jl. Veteran, Malang, East Java, Indonesia, 65145
How to cite:

Ma'aruf, W., Rosyidi, D., Radiati, L, E., \& Purwadi. (2019). Pengaruh Jenis dan Proporsi Penggunaan Tepung Jagung Terhadap Daya Ikat Air dan Kualitas Organoleptik dari Nugget Ayam Kampung. Jurnal Ilmu dan Teknologi Hasil Ternak, 14 (1), 38-49 
lebih memilih mengkonsumsi ayam kampung (Rukmana, 2003). Produk daging ayam olahan yang paling digemari masyarakat sekarang ini adalah nugget. Nugget ialah suatu bentuk produk daging giling yang dibumbui, kemudian diselimuti oleh perekat tepung, pelumuran tepung roti (breading) dan digoreng setengah matang lalu dibekukan untuk mempertahankan mutunya selama penyimpanan (Permadi dkk., 2012). Gumilar dkk. (2011) menjelaskan bahwa, pembuatan nugget memerlukan bahan pengisi (filler) yang mampu mengikat air namun mempunyai pengaruh yang kecil pada emulsifikasi.

Penambahan karbohidrat atau bahan pengisi pada nugget dapat mengurangi biaya yang berasal dari bahan utama yaitu daging (Abubakar et al., 2011). Salah satu bahan pengisi yang dapat dipergunakan pada pembuatan nugget ayam ialah tepung jagung. Tepung jagung sangat baik untuk produk-produk emulsi karena mampu mengikat air dan menahan air tersebut selama pemasakan (Wellyalina and Aisman, 2013). Suarni (2009) menyatakan, jagung mempunyai ukuran garanula pati jagung yang cukup besar sehingga memperlihatkan ketahanan yang besar pada perlakuan panas dan air. Tepung jagung juga merupakan pangan fungsional yang mengandung protein tinggi, sehingga tidak memerlukan bahan subsititusi lain dalam aplikasinya.

Keunggulan tepung jagung dibandingkan tepung lainnya, yaitu mempunyai kandungan karotenoid dan serat. Karotenoid, seperti $\boldsymbol{\beta}$-karoten, $\alpha$-karoten dan fucoxanthin merupakan antioksidan alami yang dapat meredam radikal bebas, dimana radikal bebas dapat menyebabkan kerusakan sel yang bersifat karsiogenik. Sifat fisikokimia yang perlu diperhatikan dalam pemilihan varietas jagung diantaranya ialah daya serap air (DSA), daya serap minyak (DSM), dan sifat emulsi. Daya serap minyak dan daya serap air memberi gambaran kemampuan tepung mengikat air dan minyak, sehingga dapat dijadikan petunjuk dalam pengolahan. Sementara Wellyana and Aisman (2013) menjelaskan, kualitas nugget salah satunya dipengaruhi oleh jumlah atau konsentrasi bahan pengisi yang ditambahkan, sehingga perlu diketahui persentase tepung jagung yang sesuai untuk nugget ayam kampung. Penelitian ini bertujuan untuk mengetahui pengaruh jenis dan proporsi tepung jagung terhadap sifat daya ikat air dan organoleptik dari nugget ayam kampung.

\section{MATERI DAN METODE}

\section{Materi dan Alat}

Materi. Materi yang digunakan pada penelitian untuk pembuatan nugget ayam kampung terdiri dari daging ayam kampung dan 5 jenis tepung jagung yaitu: jagung kuning, jagung pulen, jagung ungu, jagung Provit A1, dan jagung provit A2. Materi pendukung yang digunakan yaitu tepung roti, susu skim bubuk, es batu, minyak goreng, minyak jagung, bumbu - bumbu meliputi garam, bawang putih, dan lada. Disamping itu, juga ada sejumlah bahanbahan kimia yang digunakan untuk analisis proksimat.

Alat. Peralatan yang digunakan untuk pembuatan nugget: terdiri atas alat penggiling (food proscessor), timbangan, freezer, kompor, alat penggoreng, mangkok, loyang, plastik pembungkus dan peralatan masak lainnya. Juga peralatan yang digunakan untuk analisis kimia.

\section{Pembuatan Tepung Jagung}

Kelima jenis jagung yang akan dipergunakan dalam penelitian ini, terlebih dahulu dijadikan tepung jagung. Metode yang digunakan dalam pembuatan tepung jagung ialah metode penggilingan kering. Tepung jagung yang dipergunakan pada penelitian ialah tepung yang lolos ayakan 100 mesh.

\section{Proses Pembuatan Nugget}

Metode pembuatan nugget mempergunakan aplikasi dari Heinz and Hautzinger (2007), dengan 
mempergunakan tepung jagung pada nugget daging ayam kampung. Daging ayam kampung sebanyak $300 \mathrm{~g}$ digiling, kemudian ditambahkan serpihan es, garam, selanjutnya ditambahkan gula, merica, bawang putih, susu skim, minyak jagung. Jenis tepung jagung dan persentase tepung jagung pada nugget yang dipergunakan sesuai dengan perlakuan masing-masing.

Semua bahan diaduk sehingga menjadi adonan yang homogen. Adonan nugget tersebut dicetak dalam loyang aluminium dan dialasi dengan menggunakan plastik, kemudian dikukus. Pengukusan dilakukan hingga suhu internal adonan mencapai $60^{\circ}$ sampai $70^{\circ} \mathrm{C}$ kurang lebih selama 30 menit, setelah selesai dikukus, adonanan nugget yang telah didinginkan dalam suhu ruang kemudian dimasukkan ke dalam refrigerator selama 30 menit.

Adonan yang telah padat tersebut kemudian dipotong-potong dengan ukuran kurang lebih $4 \times 4 \mathrm{~cm}$ dengan ketebalan $1 \mathrm{~cm}$, selanjutnya adonan dilumuri dengan perekat tepung (batter) yang terbuat dari campuran $80 \mathrm{~g}$ maizena dan $100 \mathrm{ml}$ air, kemudian dilumuri dengan tepung roti dan dibalurkan dengan telur dan dilumuri kembali dengan tepung roti. Dilakukan penggorengan awal menggunakan minyak terendam selama 30 detik pada suhu $170^{\circ} \mathrm{C}$. Nugget dikemas dalam plastik dan disimpan dalam freezer dan selanjutnya dilakukan penggorengan akhir yaitu nugget digoreng selama 4 menit pada suhu $170^{\circ} \mathrm{C}$.

\section{Evaluasi daya ikat air dan kualitas organoleptik}

Bahan pangan memiliki standarisasi kualitas produk. Standarisasi kualitas meliputi uji fisik dan uji organoleptik. Daya ikat air (DIA) adalah kemampuan dari nugget dalam mengikat air di dalam daging. Nilai DIA dapat ditentukan dengan metode Hamm sesuai petunjuk Soeparno (2005). Pertama-tama meletakkan sampel sebanyak 0,3 $\mathrm{g}$ di atas kertas saring Whatman 42 dan kemudian meletakkan diantara 2 plat kaca yang diberi beban $35 \mathrm{~kg}$ selama 5 menit. Menandai dan menggambar luasan area yang tertutup sampel daging yang telah menjadi pipih dan basah disekeliling kertas saring pada kertas grafik dengan bantuan alat candling dan dari gambar tersebut diperoleh area basah setelah dikurangi area yang tertutup sampel (dari total area). Kandungan air sampel (pada area basah) dapat di ukur dengan menggunakan rumus:

$$
\begin{aligned}
& \text { miligram } \mathrm{H}_{2} \mathrm{O}=\frac{\text { area basah }(\mathrm{cm} 2)}{0,0948}-8,0=x \\
& \text { kadar area basah }=\frac{x}{\text { berat sampel }(\mathrm{g})} \times 100 \% \ldots \ldots \ldots \ldots \ldots \ldots \ldots \ldots \ldots \ldots \\
& \text { Daya ikat air }=\% \text { kadar air }-\% \text { kadar air area basah }
\end{aligned}
$$

Penentuan kualitas organoletik diukur menggunakan skala hedonic dengan 7 poin, dimana produk dengan skor 7 berarti "sangat memuaskan", dan produk dengan skor 1 berarti "sangat tidak memuaskan". Panelis uji sensorik berjumlah 35 orang baik dosen dan mahasiswa yang sudah terlatih. Kualitas organoleptic yang diukur, yaitu: warna, tekstur dan kekenyalan, cita rasa (flavor) dan penerimaan umum.

\section{Rancangan Percobaan}

Penelitian akan menggunakan rancangan acak lengkap factorial, terdiri atas 2 faktor. Faktor pertama adalah 5 (lima) jenis tepung jagung, yaitu: jagung kuning (J1); jagung pulen (J2); jagung ungu (J3); jagung Provit A1 (J4); dan jagung provit A2 (J5).

Faktor kedua adalah prosentase tepung jagung yang digunakan sebagai bahan pengisi terhadap berat daging, yang terdiri atas 4 taraf, yaitu: $\mathrm{T} 1=10 \%(40 \mathrm{~g})$; $\mathrm{T} 2=15 \%(60 \mathrm{~g}) ; \mathrm{T} 3=20 \%(80 \mathrm{~g}) ; \mathrm{T} 4=$ $25 \%(100 \mathrm{~g})$. Dari kedua faktor tersebut diperoleh 20 kombinasi perlakuan, dimana setiap kombinasi perlakuan diulang sebanyak 3 kali. 


\section{Variabel yang diukur}

Variabel yang diukur dalam penelitian ini adalah daya ikat air, dan kulitas organoleptik dari nugget ayam kampung.

\section{Analisa Data}

Data sifat daya ikat air dianalisis dengan menggunakan analisa keragaman. Apabila dari hasil analisis ragam terdapat pengaruh yang nyata diantara perlakuan yang diteliti, maka dilakukan uji lanjut dengan uji BNT (Beda Nyata Jujur) pada taraf $5 \%$, sedangkan data-data kualitas organoleptik di analisis menggunakan analisis statistik deskriptif.

\section{HASIL DAN PEMBAHASAN}

\section{Daya Ikat Air}

Kapasitas menahan air (WHC) adalah kemampuan daging untuk menahan air ketika kekuatan (panas, tekanan) diterapkan. Air adalah komponen utama (sekitar 75\%) jaringan otot. Sebagian besar ada di lapisan sekitar molekul-molekul polar dan antara lapisan bahan seluler. Mayoritas berada di ruang antar-molekul antara protein larut garam (aktin, myosin) dari jaringan otot, baik dalam miofibril, antara miofibril dan antara miofibril dan membran sel (sarcolemma), maupun antara sel-sel otot dan antara buntalan otot (kelompok sel otot).

Setelah otot dipanen jumlah air dan lokasi air dalam daging dapat berubah tergantung pada berbagai faktor yang terkait dengan jaringan itu sendiri dan bagaimana produk tersebut diolah (Honikel, 2004; Brewer, 2010). Data rataan pengaruh interaksi perlakuan terhadap daya ikat air nugget ayam kampung disajikan pada Tabel 1.

Daya ikat air dari nugget ayam kampung dalam penelitian ini berada pada kisaran 47,75 - 61,64\%, dimana perlakuan J2T3 (jagung pulen taraf penggunaan $80 \mathrm{~g}$ ) memiliki prosentasi daya ikat air terrendah, sedangkan yang tertinggi pada perlakuan J5T4 (jagung provit A2 taraf penggunaan
100 g). Berdasarkan uji BNT, terdapat 10 kombinasi perlakuan yang menghasilkan nugget dengan daya ikat air antara 47,75 52,79\%, yaitu: J2T3, J3T2, J1T4, J3T1, J1T1, J2T2, J3T3, J1T3, J4T2, dan J2T1, dimana prosentase daya ikat air tersebut berbeda sangat nyata $(\mathrm{P}>0,01)$ lebih rendah dari perlakuan-perrlakuan J5T4, J5T2 J4T4 dan J2T4, dan J5T3, yang memiliki daya ikat air berkisar 57,89- 61,64\%.

Sementara itu, perlakuan-perlakuan J5T4 dan J5T2 selain berbeda sangat nyata $(\mathrm{P}<0,01)$ lebih tinggi dari perlakuan J4T1, juga masih berbeda nyata $(\mathrm{P}<0,05)$ dari perlakuan-perlakuan J3T4, J1T2 dan J5T1. Maliluan dkk. (2013) melaporkan dalam pembuatan nugget ayam menggunakan substitusi bahan pengisi antara tepung gandum dan tepung beras sebanyak $40 \mathrm{~g}$, hasil prosentasi daya ikat air berada pada kisaran 30,59 - 38,89\%, sementara Lukman dkk. (2009) melaporkan penelitiannya terhadap 5 jenis nugget ayam komersil mendapatkan daya ikat air berada pada kisaran $34,54-51,57 \%$.

Hasil-hasil penelitian tersebut ternyata terpaut lebih rendah dari hasil penelitian ini, dimana dari penggunaan bahan pengisi lima jenis tepung jagung pada taraf $40 \mathrm{~g}$ diperoleh daya ikat air antara 50,02 - 55,36\%. Kondisi ini dimungkinkan oleh adanya kandungan komponen serat larut air dalam tepung jagung terutama $\beta$-glukan yang berpengaruh pada daya ikat air lebih tinggi. Semakin tinggi kadar $\beta$-glukan dalam tepung, semakin tinggi pula daya ikat air tepung tersebut. Dalam penelitian ini, pengikatan air berlangsung melalui proses gelatinisasi dari granula pati jagung, dimana dengan adanya air dan pemanasan terjadi proses penguraian ikatan antarmolekul molekul pati, yang memungkinkan situs ikatan hidrogen (hidrogen $(\mathrm{H})$, hidroksil $(\mathrm{OH})$ dan oksigen (O) ) melibatkan lebih banyak air. Proses yang terjadi pada granula pati: pembengkakan granula, kristal atau struktur heliks ganda mencair, dan terjadi pencucian amilosa (Berggren, 2017). 
Tabel 1. Pengaruh interaksi perlakuan terhadap kadar air, daya ikat air dan susuk masak nugget ayam kampung

\begin{tabular}{c|l}
\hline \multirow{2}{*}{ Interaksi } & Daya Ikat Air (\%) \\
\cline { 2 - 2 } & Rataan \\
\hline J1T1 & $50,09^{\text {ghi }}$ \\
J1T2 & $55,08^{\text {cdefg }}$ \\
J1T3 & $51,63^{\text {fghi }}$ \\
J1T4 & $48,92^{\text {hi }}$ \\
\hline J2T1 & $52,79^{\text {gghi }}$ \\
J2T2 & $50,58^{\text {ghi }}$ \\
J2T3 & $47,75^{\text {i }}$ \\
J2T4 & $58,73^{\text {bcd }}$ \\
\hline J3T1 & $50,02^{\text {ghi }}$ \\
J3T2 & $48,12^{\text {i }}$ \\
J3T3 & $50,64^{\text {fghi }}$ \\
J3T4 & $54,87^{\text {cdefg }}$ \\
\hline J4T1 & $53,69^{\text {efgh }}$ \\
J4T2 & $51,64^{\text {fghi }}$ \\
J4T3 & $55,96^{\text {bcdef }}$ \\
J4T4 & $59,98^{\text {abc }}$ \\
\hline J5T1 & $55,36^{\text {cdefg }}$ \\
J5T2 & $60,90^{\text {ab }}$ \\
J5T3 & $57,89^{\text {abcde }}$ \\
J5T4 & $61,64^{\text {a }}$ \\
\hline
\end{tabular}

Keterangan: Superskrip yang berbeda pada kolom yang sama menunjukkan perbedaan yang nyata $(\mathrm{P}<0,01 ; \mathrm{P}<0,05)$

Pati jagung, bersifat stabil dalam penyimpanan secara kering, bahkan untuk waktu yang tidak terbatas. Meskipun granula pati secara fisik tahan lama, namun pada kenyataannya mereka dapat dengan mudah mengalami gangguan. Jika granula pati dalam suspensi air dipanaskan secara bertahap, mereka mulai menyerap air. Granula menghidrasi, meningkatkan ukuran dan akhirnya kehilangan integritas struktural mereka. Kondisi ini, menyebabkan hilangnya karakteristik birefringence dan opacity (tingkat transparansi), peningkatan viskositas, dan akhirnya pembentukan pasta atau gel. Proses ini disebut sebagai tepung pasta atau gelatinisasi. (Corn Refiners Association, 2006). Gelatinisasi adalah proses transisi fisik bersifat endotermis yang merusak keteraturan molekuler granula dan melibatkan proses pembengkakan granula, pelelehan kristal, hilangnya birefringence dan pelarutan pati (Shamekh, 2002). Selama proses pemanasan, air pertama diserap dalam ruang amorf pati, yang mengarah ke fenomena pembengkakan, kemudian aiir masuk melalui daerah amorf yang merupakan area ikatan struktur heliks ganda yang kuat dari amilopektin.

Pada suhu kisaran suhu tertentu daerah kristalin tidak memungkinkan air untuk masuk. Panas menyebabkan daerah tersebut berdifusi, rantai amilosa melarut, terurai ke dalam bentuk amorf dan jumlah dan ukuran daerah kristalin menurun, sehingga penetrasi air meningkat secara acak dalam dalam struktur granula pati, dan menyebabkan pembengkakan, akhirnya 
larutan molekul amilosa meresap ke dalam air sekitarnya dan struktur granula hancur. Suhu gelatinisasi adalah suhu dimana sifat birefringence dan pola difraksi sinar-X granula pati mulai hilang. Suhu gelatinisasi diawali dengan pembengkakan yang irreversible granula pati dalam air panas dan diakhiri tepat ketika granula pati telah kehilangan sifat kristalnya. Winarno (2004) menyatakan bahwa suhu dimana sifat birefringence granula pati mulai menghilang dihitung sebagai suhu awal gelatinisasi. Suhu gelatinisasi pati jagung berada pada kisaran $61-72^{\circ} \mathrm{C}$.

Daya ikat air, merupakan bagian integral dari kualitas produk dalam hal tekstur, juiciness dan kelembutan. Glikolisis post mortem menghasilkan asam laktat, yang menurunkan $\mathrm{pH}$ dan menyebabkan hilangnya daya ikat air oleh protein melalui beban penghalang (chargeshielding). Selama konversi otot daging, asam laktat menumpuk di jaringan yang mengarah ke pengurangan dalam $\mathrm{pH}$ daging.

Setelah $\mathrm{pH}$ telah mencapai titik isoelektrik $(\mathrm{PI})$ protein utama, terutama myosin $(\mathrm{PI}=5,4)$, muatan bersih protein adalah nol, yang berarti angka muatan positif dan negatif dalam protein pada dasarnya sama. Kelompok-kelompok positif dan negatif dalam protein tersebut saling menarik satu sama lain dan hasilnya dalam pengurangan jumlah air yang dapat ditarik dan ditahan oleh protein tersebut (Lonergan and Lonergan, 2005).

\section{Uji Karakteristik Nugget Ayam Kampung}

Beberapa faktor yang mempengaruhi persepsi konsumen terhadap kualitas nugget ayam kampung berhubungan erat dengan sensasi organ pancaindera, meliputi: warna, tekstur dan kekenyalan, cita rasa, dan penerimaan konsumen terhadap produk tersebut. Hasil uji organoleptik terhadap nugget ayam kampung yang menggunakan bahan pengisi jenis dan proporsi tepung jagung, disajikan pada Tabel 2.

\section{Warna}

Kesan pertama yang diterima konsumen terhadap produk pangan dibentuk melalui visual. Northcutt (2009) menyatakan, warna daging unggas dimasak atau mentah adalah faktor penting karena konsumen mengasosiasikannya dengan kesegaran produk, yang kemudian mengambil keputusan untuk membeli atau tidak produk tersebut berdasarkan opini daya tarik mereka. Sejalan dengan itu, Pérez-Alvarez and Fernández-López (2012) mengemukakan, warna merupakan aspek utama yang mendefinisikan kualitas suatu produk pangan, dan mempengaruhi pilihan konsumen.

Berdasarkan analisis deskripsi statistik dari hasil penilaian panelis pada uji organoleptik menunjukkan rataan skor terhadap warna nugget ayam kampung dari semua kombinasi perlakuan, berkisar antara $2,83-6,43$, dimana skor terrendah diperoleh pada perlakuan J3T3, termasuk pada kategori "agak tidak menarik", sedangkan skor tertinggi pada perlakuan J4T1 termasuk dalam kategori "menarik". Terdapat 3 (tiga) kombinasi perlakuan yang menurut penilaian panelis termasuk dalam kategori "menarik", yaitu: J4T1, J5T1 dan J1T1, dengan skor masing-masing 6,43, 6,40 dan 5,66. Pérez-Alvarez and Fernández-López (2012) mengemukakan, Kualitas sensorik, terutama warna dan penampilan daging, dapat dipengaruhi baik oleh faktor internal maupun eksternal.

Kromoprotein, karoten, dan karotenoprotein penting dalam warna daging. Karoten bertanggung jawab untuk warna lemak daging sapi, daging unggas dan kulit, juga pada ikan. Dari hemoglobinhemoglobin yang hadir dalam otot post mortem, mioglobin merupakan pigmen utama yang paling bertanggung jawab untuk warna. Sitokrom-sitokrom adalah metalloprotein yang bersama dengan kelompok heme berperan dalam pewarnaan daging. Peran utama dari lemak dalam kecerahan produk daging.Pada produk daging olahan seperti dalam penelitian ini, warna daging ayam juga dipengaruhi oleh 
faktor-faktor non enzimatik, seperti perubahan suhu pada pengolahan. Seperti terjadinya reaksi interaktif dari protein dan pigmen karoten dari daging olahan, Kilincceker (2013) mengemukakan protein dan pigmen karoten menyebabkan pelepuhan pada produk ayam, namun tidak menyebabkan permukaan produk retak, dan memunculkan warna kuning keemasan. Demikian pula, Barbut (2015) menyatakan bahwa proses karamelisasi dan kandungan komponen lainnya dalam bahan pangan dapat meningkatkan reaksi pencoklatan Maillard, dimana terjadi reaksi antara gulagula reduksi dan asam-asam amino reduksi, yang meningkatkan ciri warna keemasan pada produk akhir daging olahan.

\section{Tekstur dan kekenyalan}

Tekstur merupakan salah satu faktor kualitas yang paling penting yang terkait dengan kepuasan tertinggi konsumen terhadap produk daging unggas (Fletcher, 2002). Analisis deskripsi statistik dari hasil penilaian panelis pada uji organoleptik, menunjukkan rataan skor terhadap tekstur nugget ayam kampung dari semua kombinasi perlakuan, berkisar antara 3,54 5,69 , dimana perlakuan yang memiliki skor terrendah adalah J3T4, termasuk pada kategori "agak kasar", sedangkan skor tertinggi pada perlakuan J4T1, termasuk dalam kategori "halus". Tekstur "halus" yang diperoleh dari penggunaan jagung provit A1 dan provit A2, sama dengan hasil yang diperoleh penelitian Polizer, et al., (2015), dengan skala Hedonic berkisar 7,28 - 7,42 atau "halus" (dari skala $1-9$ ).

Fletcher (2002) menyatakan, ada dua kontributor utama keempukan daging unggas adalah kematangan dari jaringan ikat dan kemapanan kontraktil protein myofibrillar. Kematangan jaringan ikat melibatkan lintas ikatan kimia kolagen dalam otot, karena ikatan silang kolagen meningkat bersama usia, daging umumnya lebih keras pada hewan yang lebih tua. Faktor kedua, keadaan kontraktil protein myofibril, terutama fungsi dari tingkat dan kepadatan perkembangan rigor mortis.
Pemanasan menghasilkan pelunakan jaringan ikat yang disebabkan oleh konversi kolagen menjadi gelatin dan pengerasan serat daging yang disebabkan oleh pembekuan panas protein myofibrillar (Murphy and Marks, 2000).

\section{Kekenyalan}

Salah satu kelengkapan penting dipenuhi pada produk daging olahan adalah sifat kenyal, dimana produk tersebut mampu kembali ke bentuk semula setelah ada perlakuan gaya. Kekenyalan nugget ayam berhubungn erat dengan tekstur dan sifat-sifat lainnya yang menentukan kualitas preferensi dan daya tarik konsumen. Analisis deskripsi statistik dari hasil penilaian panelis pada uji organoleptik, menunjukkan rataan skor terhadap sifat kekenyalan nugget ayam kampung dari semua kombinasi perlakuan, berkisar antara 4,80 - 5,83, dimana terdapat 3 perlakuan yang memiliki skor terrendah yang sama, yakni: J2T1, J4T4 dan J5T4, termasuk pada kategori "agak kenyal", sedangkan skor tertinggi pada perlakuan J4T1 dan J5T1, termasuk dalam kategori "kenyal".

\section{Cita-rasa (Flavor)}

Cita-rasa merupakan perpaduan antara rasa (taste) dan aroma yang dapat mempengaruhi perilaku membeli produk daging dan preferensi konsumen Jayasena dkk. (2013). Rasa adalah persepsi multiindera yang dihasilkan melalui integrasi indera pengecap, penciuman, dan saraf trigeminal (Auvray and Spence 2008). Saraf trigeminal adalah saraf yang berperan dalam mengirimkan sensasi dari kulit bagian anterior kepala, rongga mulut dan hidung, gigi dan meninges atau lapisan otak.

Rasa biasanya dikaitkan dengan rasa dasar manis, asam, asin, dan pahit, sementara aroma dikaitkan dengan stimulasi reseptor dalam rongga hidung oleh bahan-bahan mudah menguap (volatil) yang dilepaskan oleh produk pangan (Lyon and Lyon., 2001). Analisis deskripsi 
statistik dari hasil penilaian panelis pada uji organoleptik, menunjukkan rataan skor terhadap cita-rasa nugget ayam kampung dari semua kombinasi perlakuan, berkisar antara 2,20-5,86, dimana perlakuan yang memiliki skor terrendah adalah J1T3 dan J1T4, termasuk pada kategori "tidak enak", sedangkan skor tertinggi pada perlakuan J4T1, termasuk dalam kategori "enak". Uji sensori dari cita rasa juga menunjukkan, respon panelis terhadap semua kombinasi perlakuan pada jagung kuning (J1), jagung pulen (J2) dan jagung ungu (J3) pada semua taraf penggunaannya $(\mathrm{T} 1=40 \mathrm{~g}$ $\mathrm{T} 4=100 \mathrm{~g}$ ), rata-rata memberi skor antara 2,20 - 4,29, yang termasuk pada kategori "tidak enak" sampai "netral". Sedangkan, terhadap semua kombinasi perlakuan pada jagung provit A1 (J4) dan jagung provit A2 (J5) pada semua taraf penggunaannya $(\mathrm{T} 1=40 \mathrm{~g}-\mathrm{T} 4=100 \mathrm{~g}$ ), rata-rata memberi skor antara 5,60 - 5,68, dengan kategori "enak". Hasil ini sama dengan yang dilaporkan Polizer, et al. (2015), yaitu berkisar 7,40 - 7,47 atau "enak" (dari skala $1-9)$.

Tabel 2. Rataan Uji organoleptik *)

\begin{tabular}{|c|c|c|c|c|c|c|c|c|c|c|}
\hline Perlakuan & Warna & $\mathrm{Sd}$ & $\begin{array}{c}\text { Tekst } \\
\text { ur }\end{array}$ & $\mathrm{Sd}$ & Kenyal & $\mathrm{Sd}$ & $\begin{array}{l}\text { Cita } \\
\text { rasa }\end{array}$ & $\mathrm{Sd}$ & $\begin{array}{c}\mathrm{P}- \\
\text { umum }\end{array}$ & $\mathrm{Sd}$ \\
\hline J1T1 & 5,66 & \multirow{20}{*}{ $\pm 0,98$} & 5,43 & \multirow{20}{*}{ $\pm 0,61$} & 5,17 & \multirow{20}{*}{ $\pm 0,28$} & 3,37 & \multirow{20}{*}{ $\pm 1,64$} & 4,26 & \multirow{20}{*}{$\begin{array}{c} \pm \\
1,30\end{array}$} \\
\hline $\mathrm{J} 1 \mathrm{~T} 2$ & 4,80 & & 4,09 & & 4,94 & & 2,26 & & 4,26 & \\
\hline J1T3 & 4,60 & & 4,37 & & 5,03 & & $2,20^{R}$ & & 4,23 & \\
\hline $\mathrm{J} 1 \mathrm{~T} 4$ & 4,89 & & 4,26 & & 4,89 & & $2,20^{R}$ & & 4,23 & \\
\hline J2T1 & 5,34 & & 4,71 & & $4,80^{R}$ & & 4,29 & & $2,69^{R}$ & \\
\hline $\mathrm{J} 2 \mathrm{~T} 2$ & 4,14 & & 4,20 & & 5,00 & & 2,34 & & 3,03 & \\
\hline $\mathrm{J} 2 \mathrm{~T} 3$ & 4,09 & & 4,54 & & 5,11 & & 2,46 & & 2,91 & \\
\hline J2T4 & 3,83 & & 4,89 & & 5,14 & & 2,31 & & 3,09 & \\
\hline J3T1 & 5,26 & & 4,97 & & 5,09 & & 3,74 & & 2,91 & \\
\hline J3T2 & 3,31 & & 3,66 & & 4,97 & & 2,40 & & 3,26 & \\
\hline J3T3 & $2,83^{R}$ & & 3,80 & & 5,14 & & 2,23 & & 3,46 & \\
\hline J3T4 & 3,20 & & $3,54^{R}$ & & 5,09 & & 2,40 & & 3,29 & \\
\hline J4T1 & $6,43^{T}$ & & $5,69^{T}$ & & $5,83^{T}$ & & $5,86^{T}$ & & 5,74 & \\
\hline $\mathrm{J} 4 \mathrm{~T} 2$ & 5,09 & & 4,83 & & 5,11 & & 5,80 & & 5,69 & \\
\hline $\mathrm{J} 4 \mathrm{~T} 3$ & 5,06 & & 4,86 & & 5,00 & & 5,71 & & 5,71 & \\
\hline J4T4 & 5,43 & & 4,89 & & $4,80^{R}$ & & 5,80 & & 5,71 & \\
\hline J5T1 & 6,40 & & 5,54 & & $5,83^{T}$ & & 5,80 & & 5,77 & \\
\hline $\mathrm{J} 5 \mathrm{~T} 2$ & 5,37 & & 5,06 & & 4,94 & & 5,60 & & 5,83 & \\
\hline J5T3 & 5,20 & & 4,97 & & 4,89 & & 5,80 & & $6,00^{T}$ & \\
\hline J5T4 & 5,31 & & 5,20 & & $4,80^{R}$ & & 5,77 & & 5,97 & \\
\hline
\end{tabular}

Keterangan: - Data disajikan berdasarkan anilisis statistik deskripsi sebagai nilai rataan \pm deviasi baku $(\mathrm{Sd}) ; \mathrm{n}=35$, dimana ${ }^{T}=$ skor tertinggi dan ${ }^{R}=$ skor terrendah - *) Skala Hedonic: 7= sangat suka; $6=$ suka; $5=$ agak suka; $4=$ biasa/netral; $3=$ agak tidak suka; $2=$ tidak suka; $1=$ sangat tidak suka

\section{Penerimaan Umum}

Analisis deskripsi statistik dari hasil penilaian panelis pada uji organoleptik, menunjukkan rataan skor penerimaan umum (overall acceptance) terhadap nugget ayam kampung, dari semua kombinasi perlakuan, berkisar antara 2,69-
6,00, dimana perlakuan yang memiliki skor terrendah adalah J2T1, termasuk pada kategori "tidak suka", sedangkan skor tertinggi pada perlakuan J5T3, termasuk dalam kategori "suks". Uji sensori juga, menunjukkan semua kombinasi perlakuan pada jagung provit A1 (J4) dan jagung 
provit A2 (J5) pada semua taraf penggunaannya ( $\mathrm{T} 1=40 \mathrm{~g}-\mathrm{T} 4=100 \mathrm{~g})$, memperoleh skor antara 5,69 - 6,00, yang berarti nugget ayam kampung yang menggunakan perlakuan tersebut, mendapatkan respon "suka" dari panelis. Hasil ini sama dengan hasil uji sensori "overall acceptance" (penerimaan umum) terhadap nugget ayam yang dilakukan oleh Polizer et al. (2015), Verma et al. (2015) dan Sharma et al. (2018), yaitu masuk dalam kategori "suka", meskipun mereka menggunakan skala hedonik bervariasi antara $1-8$ dan sampai 9 .

\section{KESIMPULAN}

Hasil penelitian menunjukkan, bahwa interaksi antara jenis dan taraf penggunaan tepung jagung, berpengaruh terhadap sifat daya ikat air dan karakteristik kualitas organoleptik nugget ayam kampung. Penggunaan tepung jagung provit A1 dengan taraf $40 \mathrm{~g}$ (T4J1) memberikan karakteristik kualitas nugget ayam kampung yang terbaik, karena dengan daya ikat air 53,69\%, produk nugget ini ternyata memberi sensasi yang "memuaskan" panelis untuk semua kriteria uji organoleptik, meliputi: warna, tekstur dan kekenyalan, cita-rasa dan penerimaan umum. Perlakuan yang memberikan hasil nugget yang hampir sama baiknya dengan J4T1 adalah penggunaan jagung provit A2 taraf $40 \mathrm{~g}$.

\section{DAFTAR PUSTAKA}

Abubakar, T., Suryati, \& Azizs, A. (2011). Pengaruh Penambahan Karagenan terhadap Sifat Fisik, Kimia dan Palatabilitas Nugget Daging Itik Lokal (Anas platyrynchos). (Auvray \& Spence, Eds.). Seminar Nasional Teknologi Peternakan dan Veteriner.

Barbut, S. (2015). The science of poultry and meat processing. Canada: Food Science Department University of Guelph.
Berggren, S., Hedren, E., \& Edman, K. (2007). Water Holding Capacity and Viscosity of Ingredients from Oats. The effect of $\beta$-glucan and starch content, particle size, $\mathrm{pH}$ and temperature. Sweden: Linnaeus University.

Brewer, M. (2010). Technological Quality of Meat for Processing. In: Handbook of Meat Processing. (F. Toldrá, Ed.) (1st ed.). USA: Blackwell Publishing.

Corn Refiners Association. (2006). Corn Starch. Washington, D.C: 1701 Pennsylvania Avenue.

Fletcher, D. (2002). Poultry meat quality. World's Poultry Science Journal, 58(02), 131-145. https://doi.org/10.1079/WPS20020013

Gumilar, J., Rachmawan, O., \& Nurdyanti, W. (2011). Physicochemical quality of chicken nugget using suweg (Amorphophallus campanulatus B1) flour as filler. Jurnal Ilmu Ternak, 11(1), 1-5. https://doi.org/10.24198/JIT.V11I1.393

Heinz, G., \& Hautzinger, P. (2007). Meat Processing Technology - For Small to Medium Scale Producers. Bangkok: Food And Agriculture Organization of The United Nations Regional Office For Asia And The Pacific.

Honikel, K. O. (2004). Water-holding capacity of meat. Cambridge: CABI Publishing.

Huff-Lonergan, E., \& Lonergan, S. M. (2005). Mechanisms of water-holding capacity of meat: The role of postmortem biochemical and structural changes. Meat Science, 71(1), 194-204. https://doi.org/10.1016/j.meatsci.2005.04.022

Jayasena, D. D., Ahn, D. U., Nam, K. C., \& Jo, C. (2013). Flavour chemistry of chicken meat: a review. AsianAustralasian Journal of Animal 
Sciences, 26(5), 732-742. https://doi.org/10.5713/ajas.2012.12619

Kilincceker, O. (2013). Utilization of Oat Flour as Edible Coating Material on Fried Chicken Meat Balls. Focusing on Modern Food Industry (FMFI), 2(1), 36-42.

Koswara, S. (2009). Pengolahan Unggas. Ebookpangan.Com.

Lyon, B. G., \& Lyon, C. E. (2001). Meat quality: Sensory and Instrumental Evaluations. In: Poultry Meat Processing. (A. Sams, Ed.). USA: CRC Press Taylor \& Francis Group.

Maliluan, C., Pramono, Y. B., \& Dwiloka, B. (2013). Physical and sensory characteristics of chicken nuggets with utilization rice bran to substitute wheat flour. Jurnal Aplikasi Teknologi Pangan, 2(2), 71-74.

Masruhah, L. (2008). Pengaruh Penggunaan Limbah Padat Tahu dalam Ransum terhadap Konsumsi Pakan, Pertambahan Bobot Badan dan Konversi Pakan pada Ayam Kampung (Gallus domesticus) Periode Grower (Skripsi). Malang: Jurusan Biologi Fakultas Sains dan Teknologi Universitas Islam Negeri.

Murphy, R. Y., \& Marks, B. P. (2000). Effect of meat temperature on proteins, texture, and cook loss for ground chicken breast patties. Poultry Science, $\quad 79(1), \quad 99-104$. https://doi.org/10.1093/ps/79.1.99

Northcutt, J. K. (2009). Factors Affecting Poultry Meat Quality The University of Georgia Cooperative Extension Service The University's Bull.
Pérez-Alvarez, J., \& López, J. F. (2012). Chemical and Biochemical Aspects of Color in Muscle Foods. In: Handbook of Meat, Poultry and Seafood Quality. (L. M. L \& Nollet, Eds.). John Wiley \& Sons, inc.

Perlo, F., Bonato, P., Teira, G., Fabre, R., \& Kueider, S. (2006). Physicochemical and sensory properties of chicken nuggets with washed mechanically deboned chicken meat: Research note. Meat Science, 72(4), 785-788. https://doi.org/10.1016/j.meatsci.2005.09.007

Permadi, S. N., Mulyani, S., \& Hintono, A. (2012). Kadar serat, sifat organoleptik, dan rendemen nugget ayam yang disubstitusi dengan jamur tiram putih (Plerotus ostreatus). Jurnal Aplikasi Teknologi Pangan, 1(4), 115-120.

Polizer, Y. J., Pompeu, D., Hirano, M. H., Freire, M. T. de A., \& Trindade, M. A (2015). Development and evaluation of chicken nuggets with partial replacement of meat and fat by pea fibre. Brazilian Journal of Food Technology, 18(1), 62-69. https://doi.org/10.1590/1981-6723.4914

Rukmana, R. (2003). Intensifikasi dan Kiat Pengembangan. Yogyakarta: Kanisius.

Shamekh, S. (2002). Effects of lipids, heating and enzymatic treatment on starches. Technical Research Center of Finland.

Sharma, S., Pathak, V., Singh, V. P., Awasthi, M., \& Bharti, S. (2018). Comparative quality assessment of meat nuggets prepared from meat of different food animals. Int. J. Livestock Research, 8(1), 139-148. 
Soeparno. (2005). Ilmu dan Teknologi Daging. Yogyakarta: Gadjah Mada University Press.

Suarni, S. (2017). Prospek pemanfaatan tepung jagung untuk kue kering (Cookies). Jurnal Penelitian Dan Pengembangan Pertanian, 28(2), 63-71. https://doi.org/10.21082/jp3.v28n2.2009.p63 - 71
Verma, A. K., Banerjee, R., \& Sharma, B. D. (2015). Quality characteristics of low fat chicken nuggets: effect of salt substitute blend and pea hull flour. Journal of Food Science and Technology, 52(4), 2288-2295. https://doi.org/10.1007/s13197-013-1218-1

Wellyalina, W., Azima, F., \& Aisman, A. (2013). Pengaruh perbandingan tetelan merah tuna dan tepung maizena terhadap mutu nugget. Jurnal Aplikasi Teknologi Pangan, 2(1), 9-17. 